\section{Kidney \\ Blood Pressure \\ Research}

\title{
Fructose Acutely Stimulates NHE3 Activity in Kidney Proximal Tubule
}

\author{
Gabriella D. Queiroz-Leite ${ }^{a}$ Renato O. Crajoinas ${ }^{b}$ Elida A. Neria \\ Camila N. A. Bezerra ${ }^{a}$ Adriana C. C. Girardi ${ }^{b}$ Nancy Amaral Rebouças ${ }^{a}$ \\ Gerhard Malnica \\ aDepartment of Physiology and Biophysics, Institute of Biomedical Sciences, ${ }^{b} \mathrm{Heart}$ Institute (InCor), \\ Medical School, University of São Paulo São Paulo, Brazil
}

\section{Key Words}

Fructose • In situ microperfusion • CAMP • Sodium hydrogen exchangers • LLC-PK1 cells

\begin{abstract}
Background/Aims: Fructose causes a sodium-sensitive hypertension and acutely reduces the urinary $\mathrm{Na}^{+}$excretion, suggesting that it may regulate the activity of renal tubular sodium transporters. NHE3 is highly expressed in proximal tubule (PT), along with proteins that mediate fructose transport and metabolism. The present work was outlined to investigate whether fructose modulates proximal NHE3 activity and to elucidate the molecular mechanisms underlying this modulation. Methods/Results: Using in vivo stationary microperfusion, we observed that fructose stimulates $\mathrm{NHE3}$ mediated $\mathrm{JHCO}_{3}-$ reabsorption. The MAPK pathway is not involved in this activation, as demonstrated by using of MEK/MAPK inhibitors, whereas experiments using a PKA inhibitor suggest that PKA inhibition plays a role in this response. These results were confirmed in vitro by measuring the cell $\mathrm{pH}$ recovery rate after $\mathrm{NH}_{4} \mathrm{Cl}$ pulse in LLC-PK1, a pig PT cell line, which showed reduced CAMP levels and NHE3 phosphorylation at serine-552 (PKA consensus site) after fructose treatment. Conclusions: NHE3 activity is stimulated by fructose, which increases proximal tubule $\mathrm{Na}^{+}$reabsorption. The molecular mechanisms involved in this process are mediated, at least in part, by downregulation of the PKA signaling pathway. Future studies are needed to address whether fructose-stimulated NHE3 activity may contribute to renal injury and hypertension.
\end{abstract}

Copyright $(2012$ S. Karger AG, Basel

\section{Introduction}

Fructose is a monosaccharide naturally found in fruits and honey. Currently, the primary source of fructose in the American diet is sucrose, a disaccharide composed of fructose and glucose linked in a 1:1 ratio and high fructose corn syrup (HFCS), which consists of a 


\section{Kidney Blood Pressure Research}

mixture of free fructose and glucose, usually in a 55/45 proportion [1]. HFCS is widely used in artificially sweetened food, especially in soft beverage drinks, and its consumption has been dramatically increased in the last decades [2]. Although fructose and glucose are both hexoses $\left(\mathrm{C}_{6} \mathrm{H}_{12} \mathrm{O}_{6}\right)$, there is an important structural difference between these molecules that leads to major differences in their metabolic pathways. The first difference is that fructose, as a ketone sugar, is phosphorylated by ketohexokinase (KHK); while glucose, as an aldehyde sugar, is phosphorylated by hexokinase [3]. The proximal tubule cells are, along with the liver, one of the highest sites of KHK expression [4]. Fructose enters the cells mainly through two members of the facilitated glucose transporter proteins: GLUT5, that specifically transports fructose, and GLUT2, which also transports glucose and galactose. Both of these transporters are present in kidney, especially in proximal tubules [5, 6].

Another difference between glucose and fructose is that fructose enters the glycolytic pathway by a non-regulated manner and, thus, its sustained presence could lead to disturbance of several physiological processes. Indeed, several studies have shown that elevated consumption of fructose is associated with the development of metabolic syndrome features [7-10]. Although there is not an universally accepted concept of the metabolic syndrome, most researchers agree that this syndrome is characterized by a set of conditions such as obesity, insulin resistance, dyslipidemia and hypertension [11]. This syndrome has also been suggested as a risk factor for development of chronic kidney disease in humans [12]. In fact, studies in humans and rodents demonstrated that fructose is related to the development [13] and acceleration of kidney disease [14], glomerular hypertension [15], renal inflammation [16] and tubulointerstitial injury [17].

The kidneys are directly involved in the regulation of blood pressure and, although hypertension is considered a multifactorial disease, one of the most important parameters that should be taken into account to analyze this disease is renal salt reabsorption. Sodium retention and volume expansion play an important role in the pathogenesis of essential hypertension [18]. In fact, one of the current hypothesis is that the fructose-induced hypertension would be generated, in large part, by a state of salt overload that results from enhanced salt (re)absorption in kidneys and intestine [19-21]. In this direction, Singh and coworkers showed that mice on a high fructose diet presented a significant decrease in daily urinary $\mathrm{Na}^{+}$and $\mathrm{Cl}^{-}$excretion [20]. Another evidence that $\mathrm{Na}^{+}$overload is related to the development of the fructose-dependent hypertension is that high salt intake enhances and low salt intake blunts the magnitude of hypertension in fructose fed rats [22]. Although functional studies suggest that the kidneys are negatively affected by increased consumption of fructose, the mechanisms involved in these changes have not been fully elucidated.

On the basis of these observations, the present study was outlined to investigate whether the presence of fructose in the proximal luminal tubular fluid would regulate NHE3 activity, and to elucidate the molecular mechanisms underlying this modulation.

\section{Materials and Methods}

\section{Reagents and antibodies}

The LLC-PK1 cell line was obtained from the American Type Culture Collection (Manassas, VA). Dulbecco's modified Eagle's medium (DMEM), heat-inactivated fetal bovine serum, sodium pyruvate, and penicillin-streptomycin were purchased from GIBCO Invitrogen (Grand Island, NY). BCECF-AM was obtained from Molecular Probes (Eugene, OR). HOE-694 and S3226 were gifts from Sanofi-Aventis (Frankfurt, Germany). U0126 and SB203580 were obtained from Tocris (Bristol, UK). EZ-Link sulfo-NHS-SS-biotin as well as immunopure immobilized streptavidin were purchased from Pierce (Rockford, IL). The monoclonal (MAb) anti-NHE3 antibody 3H3 was kindly provided by Dr. Daniel Biemesderfer at Yale University. The polyclonal anti-GLUT2 and anti-KHK antibodies and the monoclonal anti-GLUT5 and anti-PS552 clone 14D5 antibodies were purchased from Santa Cruz Biotechnology (Santa Cruz, CA). All other reagents were obtained from Sigma- Aldrich (St. Louis, MO), unless otherwise specified. 


\section{Kidney \\ Blood Pressure Research}

In vivo stationary microperfusion

Animal procedures and protocols were followed in accordance with the ethical principles in animal research of the Brazilian College of Animal Experimentation and were approved by the institutional animal care and use committee. The microperfusion procedure was previously described in detail [23]. Briefly, male Wistar rats (180 to $250 \mathrm{~g}$ ) were anesthetized with intramuscular ketamine $(75 \mathrm{mg} / \mathrm{Kg}$ ) and tiletamine + acepromazine $(1 \mathrm{mg} / \mathrm{Kg})$ and the left jugular vein was cannulated for infusion of $3 \%$ mannitol in isotonic saline solution, at a rate of $0.05 \mathrm{ml} / \mathrm{min}$. The left kidney was exposed by a lumbar approach and immobilized in a plastic cup. Proximal tubules were punctured by means of a double-barrelled micropipette, one barrel being used to inject FDC-green colored Ringer perfusion solution, and the other to inject Sudan-black colored castor oil, the latter used to block the injected fluid column in the lumen. Proximal tubules (identified by the colored perfusion and its transepithelial PD) were impaled by a double-barrelled asymmetric microelectrode to measure luminal $\mathrm{pH}$. The larger barrel contained the $\mathrm{H}^{+}$-ion sensitive ion-exchange resin after silanizing with hexamethyldisilazane (both from Sigma Fluka, Buchs, Switzerland) and the smaller barrel contained the reference solution $(1 \mathrm{M} \mathrm{KCl})$ colored by FDC-green. The microelectrodes were calibrated after each perfusion by immersion in solutions with known $\mathrm{pH}(100 \mathrm{mM} \mathrm{NaCl} / 20 \mathrm{mM}$ Na phosphate at pH 6.3, 7.0 and 7.8) that covered the isolated kidney. After perfusion, the rate of tubular acidification, which represents bicarbonate reabsorption, was evaluated in the green blocked perfused solution by continuously measuring the luminal pH towards the steady-state level. The voltage between the microelectrode barrels represents the luminal $\mathrm{H}^{+}$activity, which was continuously recorded by means of a microcomputer equipped with an AD converter (Lynx, São Paulo, Brazil). Luminal bicarbonate was calculated from luminal pH and arterial blood $\mathrm{PCO}_{2}$, since we have not found any difference between renal cortical $\mathrm{PCO}_{2}$ and the systemic blood $\mathrm{PCO}_{2}$ [24]. The rate of tubular acidification was expressed as the half-time of the exponential reduction of the injected $\mathrm{HCO}_{3}$ - concentration to its stationary level $\left(\mathrm{t}_{1 / 2}\right)$. Then, net $\mathrm{HCO}_{3}{ }^{-}$reabsorption $\left(\mathrm{JHCO}_{3}^{-}\right)$per $\mathrm{cm}^{2}$ of tubule epithelium per second was calculated by using the following equation:

$$
\mathrm{JHCO}_{3}^{-}=\frac{\ln 2}{\mathrm{t}_{1 / 2}}\left[\left(\mathrm{HCO}_{3}^{-}\right)_{0}-\left(\mathrm{HCO}_{3}^{-}\right)_{\mathrm{s}}\right]^{*} \underline{\mathrm{r}}
$$

Where $t_{1 / 2}$ is the half-time of bicarbonate absorption, $\mathrm{r}$ is the tubule radius and $\left(\mathrm{HCO}_{3}^{-}\right)_{0}$ and $\left(\mathrm{HCO}_{3}^{-}\right)_{s}$ are the concentrations of the injected $\mathrm{HCO}_{3}{ }^{-}$and $\mathrm{HCO}_{3}{ }^{-}$at the stationary level, respectively.

\section{Cell culture}

Cell passages 2-10 were used in all experiments. LLC-PK1 cells were maintained in $75-\mathrm{cm}^{2}$ tissue culture flasks in DMEM supplemented with $45 \mathrm{mM} \mathrm{NaHCO}_{3}, 25 \mathrm{mM}$ HEPES buffer, $0.1 \mathrm{mM}$ sodium pyruvate, $0.01 \mathrm{mM}$ nonessential amino acids, $10 \%$ (vol/vol) heat-inactivated fetal bovine serum, $100 \mathrm{U} / \mathrm{ml}$ penicillin, and $100 \mu \mathrm{g} / \mathrm{ml}$ streptomycin. Cultures were incubated at $37^{\circ} \mathrm{C}$ in a humidified $5 \% \mathrm{CO}_{2}$-air atmosphere. Cells were subcultured with $\mathrm{Ca}^{2+} / \mathrm{Mg}^{2+}$-free phosphate-buffered saline and $0.25 \%$ trypsin-EDTA. The medium was replaced every 2 days. For experiments, cells were seeded onto tissue culture plates, grown to confluence, and serum- starved for $24 \mathrm{~h}$ before studies.

\section{Fluorescence microscopy measurement of $\mathrm{pHi}$}

NHE3 activity was measured in LLC-PK1 cells grown on glass slides using the $\mathrm{NH}_{4} \mathrm{Cl}$ pulse technique and the fluorescent $\mathrm{pH}$-sensitive probe, BCECF, as previously detailed [25]. Briefly, cells grown to confluence on glass coverslips were loaded with the dye by exposure for $5 \mathrm{~min}$ to $10 \mu \mathrm{M}$ BCECF-AM in the control solution (solution 1, Table 1) and placed in a thermoregulated chamber mounted on an inverted epifluorescence microscope (Nikon, TMD). Extracellular dye was washed away with the control solution and cells were prepulsed with $20 \mathrm{mM} \mathrm{NH}_{4} \mathrm{Cl}$ (solution 2, Table 1) during 2 minutes for acid loading. Then, the glass coverslips were rinsed with control solution with or without inhibitors, as described later, to measure NHE3 activity. The fluorescence was monitored alternately using $440 \mathrm{~nm}$ (pH-insensitive) or $490 \mathrm{~nm}$ (pHsensitive) as excitation wavelengths and emission was measured at $530 \mathrm{~nm}$ by a photomultiplier-based fluorescence system (Photon Technology International, Birmingham, NJ) at time intervals of 1s. After acid pulse $\mathrm{pH}$ recovery, cells were rinsed with a $10 \mu \mathrm{M}$ nigericin high potassium solution (solution 3, Table 1) at $\mathrm{pH}$ 7.0. The ratio of the two excitation wavelengths at this point and a set of calibration curves, with $\mathrm{pH}$ ranging from 5.5 to $8.2(5.5,5.8,6.1,6.4,6.7,7.0,7.3,7.6,7.9$ and 8.2$)$ in a $10 \mu \mathrm{M}$ nigericin high potassium 


\section{Kidney \\ Blood Pressure Research}

Kidney Blood Press Res 2012;36:320-334

\begin{tabular}{l|l}
\hline DOI: $10.1159 / 000343390$ & (C) 2012 S. Karger AG, Basel
\end{tabular}

Published online: December 12, 2012

www.karger.com/kbr

Queiroz-Leite/Crajoinas/Neri et al.: roximal Tubule NHE3 Stimulation by Fructose solution were used to calculate $\mathrm{pH}_{\mathrm{i}}$, as first described by Boyarsky et al [26].

\section{Cell $p H$ recovery}

Cell pH recovery was examined after the acidification of $\mathrm{pH}_{\mathrm{i}}$ with the $\mathrm{NH}_{4} \mathrm{Cl}$ pulse technique after 2 min exposure to $20 \mathrm{mM} \mathrm{NH}_{4} \mathrm{Cl}$ (solution 2, Table 1) in the presence of external $145 \mathrm{mM} \mathrm{Na}^{+}$ (solution 1, Table 1). In all experiments, we calculated the initial rate of $\mathrm{pH}$ recovery $(\mathrm{dpH} / \mathrm{dt}, \mathrm{pH}$ units/min) in the first 2 min after the start of the $\mathrm{pH}_{\mathrm{i}}$ recovery curve by linear regression analysis. The osmolality of solutions ranged from 295 to $305 \mathrm{mosmol} / \mathrm{kgH}_{2} \mathrm{O}$ as measured by an osmometer (Osmette, Precision Systems, Philadelphia, PA).
Table 1: All values are in $\mathrm{mM}$, except for $\mathrm{pH}$. $\mathrm{HCl}$ or $\mathrm{NaOH}$ was used to titrate to the appropriate $\mathrm{pH}$

\begin{tabular}{lccc}
\hline Reagents & $\begin{array}{c}\text { Solution 1 } \\
\text { (control) }\end{array}$ & $\begin{array}{c}\text { Solution 2 } \\
\left(\mathrm{NH}_{4} \mathrm{Cl}\right)\end{array}$ & $\begin{array}{c}\text { Solution 3 } \\
\text { (high K }{ }^{+}\end{array}$ \\
\hline $\mathrm{NaCl}$ & 141.0 & 121.0 & 20.0 \\
$\mathrm{KCl}$ & 5.4 & 5.4 & 130.0 \\
$\mathrm{CaCl}_{2}$ & 1.0 & 1.0 & 1.0 \\
$\mathrm{KH}_{2} \mathrm{PO}_{4}$ & 0.4 & 0.4 & - \\
$\mathrm{MgCl}_{2}$ & 0.5 & 0.5 & 1.0 \\
$\mathrm{MgSO}_{4}$ & 0.4 & 0.4 & - \\
$\mathrm{Na}_{2} \mathrm{HPO}_{4}$ & 0.3 & 0.3 & - \\
$\mathrm{HEPES}_{\mathrm{Glucose}}$ & 10.0 & 10.0 & 5.0 \\
$\mathrm{NH}$ & 0.6 & 0.6 & - \\
pH & - & 20.0 & - \\
\hline
\end{tabular}

\section{Measurement of intracellular buffering capacity}

In our system, intracellular buffering capacity $\left(\beta_{\mathrm{i}}\right)$ corresponds to the sum of the individual buffering powers of all cytosolic buffers, excluding $\mathrm{HCO}_{3}-/ \mathrm{CO}_{2}$. Hence, estimations of $\beta_{\mathrm{i}}$ were performed with HEPESbuffered solutions. $\beta_{i}$ was determined using the technique described by Boyarsky et al. [26] and calculated as described by Weintraub and Machen [27]. The $\mathrm{H}^{+}$membrane transporters were blocked by a $\mathrm{Na}^{+}-$free solution, which had similar composition of the control solution, except that $\mathrm{NaCl}$ was replaced by NMDG ( $\mathrm{N}$-methyl-D-glucamine). After removal of $\mathrm{Na}^{+}$from the external medium, the cells were exposed to a HEPESbuffered solution containing $50 \mathrm{mM} \mathrm{NH}_{4} \mathrm{Cl}$, which was then stepwise reduced to $1 \mathrm{mM}$ in the following steps: $50,20,10,5,2.5$, and $1 \mathrm{mM}$. Calculation of $\beta_{\mathrm{i}}$ was performed according to the formula $\Delta\left[\mathrm{NH}_{4}^{+}\right]_{\mathrm{i}} / \Delta \mathrm{pH}_{\mathrm{i}}$, where the intracellular $\mathrm{NH}_{4}{ }^{+}$concentration $\left(\left[\mathrm{NH}_{4}{ }^{+}\right]_{\mathrm{i}}\right)$ was calculated from the Henderson-Hasselbalch equation on the assumption that $\mathrm{NH}_{3 \mathrm{i}}=\mathrm{NH}_{30^{\circ}}$. The values of $\beta_{\mathrm{i}}$ were used to calculate the $\mathrm{JH}^{+}$, where $\mathrm{JH}^{+}(\mathrm{mM} / \mathrm{min})=$ $\mathrm{dpH}_{\mathrm{i}} / \mathrm{dt}$ ( $\mathrm{pH}$ units $\left./ \mathrm{min}\right) \times \beta_{\mathrm{i}}(\mathrm{mM} / \mathrm{pH}$ units).

\section{Cell surface biotinylation}

LLC-PK1 cells were grown to confluence on 6 well plates and treated or not with 3mM fructose for 5, 15 and $30 \mathrm{~min}$. The assay was performed as described previously [28]. Briefly, cells were rinsed twice in ice-cold PBS-Ca-Mg (PBS with $0.1 \mathrm{mM} \mathrm{CaCl}_{2}, 1.0 \mathrm{mM} \mathrm{MgCl}_{2}$ ) and surface membrane proteins were then biotinylated by incubating the cells twice for $25 \mathrm{~min}$ with $2 \mathrm{ml}$ of ice-cold biotinylation buffer (150 $\mathrm{mM}$ $\mathrm{NaCl}, 10 \mathrm{mM}$ triethanolamine, $2 \mathrm{mM} \mathrm{CaCl}_{2}$, and $2 \mathrm{mg} / \mathrm{ml}$ EZ-Link sulfo-NHS-SSbiotin). Cells were then rinsed twice for 20 min with a quenching buffer (PBS-Ca-Mg, $100 \mathrm{mM}$ glycine), washed twice with ice-cold PBSCa-Mg, and scraped into ice-cold solubilization buffer (50 mM Tris, $150 \mathrm{mM} \mathrm{NaCl}, 1 \mathrm{mM}$ EDTA, 0.5\% sodium deoxycholate, $1 \%$ Triton X-100, pH 7.4) containing protease inhibitors $(0.7 \mu \mathrm{g} / \mathrm{ml}$ pepstatin A, $0.5 \mu \mathrm{g} / \mathrm{ml}$ leupeptin, and $40 \mu \mathrm{g} / \mathrm{ml} \mathrm{PMSF}$ ). After lysis on ice for $60 \mathrm{~min}$, extracts were centrifuged for $10 \mathrm{~min}$ at 14,000 $g$ at $4{ }^{\circ} \mathrm{C}$. The protein concentration in the supernatants was measured [29], and aliquots of cell lysates containing equal protein amount $(500 \mu \mathrm{g})$ were equilibrated with streptavidin-agarose beads at $4^{\circ} \mathrm{C}$. The beads were then washed five times in ice-cold solubilization buffer. Biotinylated proteins were released by incubation in Laemmli buffer and subjected to SDS-PAGE and immunoblotting.

\section{SDS-PAGE and immunoblotting}

Proteins were solubilized in sample buffer (2\% SDS, 20\% glycerol, $100 \mathrm{mM}$ dithiothreitol, $50 \mathrm{mM}$ Tris pH 6.8, 0.05\% bromophenol blue) and separated by SDS-PAGE using 7.5\% polyacrylamide gels. Proteins were then transferred from the polyacrylamide gel to a polyvinylidene difluoride (PVDF) microporous membrane (Immobilon-P; Millipore, Bedford, MA) and incubated with blocking solution (5\% nonfat dry milk and $0.1 \%$ Tween 20 in PBS buffer, pH 7.0) for $1 \mathrm{~h}$ at room temperature to block nonspecific binding, followed by overnight incubation with 1:200 anti-GLUT2, 1:200 anti-GLUT5, 1:200 anti-KHK, 1:1,000 antiPS552 [30], 1:500 anti-NHE3 [31] and 1:50,000 anti-actin at $4{ }^{\circ} \mathrm{C}$ in blocking solution. The membranes were then washed five times in blocking solution and incubated for $1 \mathrm{~h}$ with horseradish peroxidase-conjugated IgG secondary antibodies. Membranes were again washed 5 times with blocking solution and then rinsed 


\section{Kidney \\ Blood Pressure Research}

with PBS buffer. Bound antibody was detected by enhanced chemiluminescence (ECL) (GE Healthcare, Piscataway, NJ) according to manufacturer's protocols. The visualized bands were digitized using the ImageScanner LAS 4000 mini (GE Health Care) and quantified using ImageJ software.

Intracellular cAMP measurement

Cellular cAMP was measured by using a competitive assay (Cyclic AMP EIA Kit, Cayman, Ann Arbor, MI), following the manufacturer's instructions. Cells were grown to confluence on 24 well plates and treated with $10 \mu \mathrm{M}$ forskolin, an adenylyl cyclase activator; and $100 \mu \mathrm{M}$ 3-isobutyl-1-methylxanthine (IBMX), a phosphodiesterase inhibitor, and treated or not with $3 \mathrm{mM}$ fructose for 5, 15 and $30 \mathrm{~min}$. Cells were incubated with $0.1 \mathrm{M} \mathrm{HCl}$ for $20 \mathrm{~min}$ at room temperature, scraped and centrifuged at 1,000 $\mathrm{g}$ for $10 \mathrm{~min}$. Samples were then incubated for $18 \mathrm{~h}$ in a plate pre-coated with mouse monoclonal anti-rabbit IgG in the presence of the cAMP Tracer (competitor) and specific antiserum to cAMP. The plate was washed 5 times and developed for 75 min with Ellman's reagent. The absorbance was read in a spectrophotometer at 420 $\mathrm{nm}$. cAMP concentration was calculated by interpolation from a standard curve. Cellular protein content was determined by using the Bicinchoninic protein assay and cAMP content was normalized to protein concentration. The results were expressed in percentage of the cAMP content present in control samples.

Statistics

Values are presented as means \pm SE and $n$ indicating the number of observations. Statistical significance was determined by ANOVA followed by the Bonferroni post test. The Student t-test was used when indicated. P value $<0.05$ was considered statistically significant. The program "Graph Pad Prism 5" (Graph Pad Software, San Diego, CA) was used to calculate significance.

\section{Results}

Modulation of $\mathrm{HCO}_{3}$ reabsorption by fructose in proximal tubules

To determine whether fructose modulates proximal tubule transport function, the $\mathrm{HCO}_{3}$ reabsorption was measured by in vivo stationary microperfusion. Different concentrations of fructose were perfused in proximal tubules and the results of these experiments showed that $1 \mathrm{mM}$ of fructose did not exert any effect on $\mathrm{HCO}_{3}{ }_{3}^{-}$reabsorption when compared to the control group $\left(1.751 \pm 0.183 \mathrm{nmol} / \mathrm{cm}^{2} \mathrm{x} \mathrm{s}\right.$ in $1 \mathrm{mM}$ fructose group versus $2.082 \pm 0.101$ $\mathrm{nmol} / \mathrm{cm}^{2} \mathrm{x} \mathrm{s}$ in the control group), whereas $2 \mathrm{mM}$ fructose $\left(2.869 \pm 0.196 \mathrm{nmol} / \mathrm{cm}^{2} \mathrm{x} \mathrm{s}\right.$ in $2 \mathrm{mM}$ fructose group versus $2.082 \pm 0.101 \mathrm{nmol} / \mathrm{cm}^{2} \mathrm{x} \mathrm{s}$ in the control group, $P<0.01$ ) and 3 $\mathrm{mM}$ fructose $\left(2.780 \pm 0.137 \mathrm{nmol} / \mathrm{cm}^{2} \mathrm{x} \mathrm{s}\right.$ in $3 \mathrm{mM}$ fructose group versus $2.082 \pm 0.101 \mathrm{nmol} /$ $\mathrm{cm}^{2} \mathrm{x}$ s in control group, $P<0.01$ ) significantly increased the $\mathrm{JHCO}_{3}{ }^{-}$in proximal tubules when compared to the control group. To investigate whether this fructose effect on $\mathrm{JHCO}_{3}^{-}$was specific of this carbohydrate, we perfused the proximal tubules with the same concentrations of glucose. We were not able to show any difference between the control group and any of the glucose concentration studied, suggesting that the stimulatory effect of fructose on $\mathrm{JHCO}_{3}^{-}$, at this concentration range, was a specific effect of this hexose. The results of this set of experiments are shown in Fig. 1A. To determine whether fructose stimulates specifically NHE3 activity, in vivo microperfusion experiments were performed in the presence and absence of $5 \mu \mathrm{M}$ of S3226, a specific NHE3 inhibitor [32]. In our experiments, the $\mathrm{HCO}_{3}$ reabsorption was reduced by approximately $57 \%$ in the presence of S3226 $(2.082 \pm 0.101$ $\mathrm{nmol} / \mathrm{cm}^{2} \mathrm{x}$ s in control group versus $0.897 \pm 0.075 \mathrm{nmol} / \mathrm{cm}^{2} \mathrm{x}$ s in control $+\mathrm{S} 3226$ group, $P$ $<0.001$, Fig. 1B), confirming that NHE3 is the major responsible for $\mathrm{HCO}_{3}^{-}$reabsorption and $\mathrm{H}^{+}$secretion in proximal tubules. The net inhibition found in the present work was consistent with maximal inhibition of NHE3-mediated $\mathrm{HCO}_{3}^{-}$reabsorption showed by others using higher S3226 concentration $(10 \mu \mathrm{M})$, excluding the possibility of incomplete inhibition due to low concentration. In fact, $1 \mu \mathrm{M}$ of S3226 is sufficient to achieve maximal NHE3 inhibition, as shown by Wang and coworkers [33]. The results of our experiments using S3226 showed that $2 \mathrm{mM}$ fructose stimulates the NHE3-mediated $\mathrm{HCO}_{3}^{-}$reabsorption in proximal tubules (Fig. 1B). There was no significant difference between control and fructose groups in the 


\section{Kidney Blood Pressure Research}
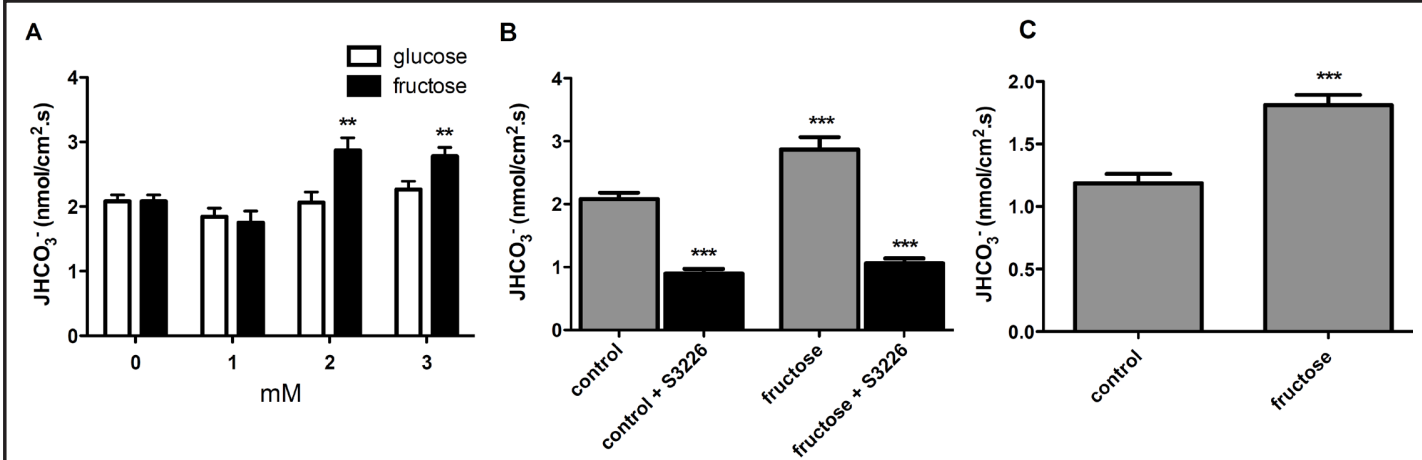

Fig. 1. Fructose stimulates bicarbonate reabsorption $\left(\mathrm{JHCO}_{3}^{-}\right)$in renal proximal tubules. $\mathrm{JHCO}_{3}^{-}$was evaluated by stationary microperfusion and continuous measurement of luminal $\mathrm{pH}$. A: $\mathrm{JHCO}_{3}-$ of proximal tubule perfused with $0 \mathrm{mM}(\mathrm{n}=21), 1 \mathrm{mM}(\mathrm{n}=7), 2 \mathrm{mM}(\mathrm{n}=16)$ and $3 \mathrm{mM}(\mathrm{n}=17)$ of fructose (black bars) and tubules perfused with $0 \mathrm{mM}(\mathrm{n}=21), 1 \mathrm{mM}(\mathrm{n}=9), 2 \mathrm{mM}(\mathrm{n}=11)$ and $3 \mathrm{mM}(\mathrm{n}=11)$ of glucose (white bars). ${ }^{* *} \mathrm{P}<0.01$ versus control group $(0 \mathrm{mM})$. B: The effect of $2 \mathrm{mM}$ fructose on $\mathrm{JHCO}_{3}{ }^{-}$was evaluated by stationary microperfusion and continuous measurement of luminal pH in the absence and presence of $5 \mu \mathrm{M}$ S3226, a specific NHE3 inhibitor. ${ }^{* * *} \mathrm{P}<0.001$ versus control group. $\mathrm{n}=21$ (control), $\mathrm{n}=11$ (control + S3226), $\mathrm{n}=16$ (fructose) and $\mathrm{n}=10$ (fructose + S3226). C: S3226 sensitive component of the $\mathrm{JHCO}_{3}{ }^{-}$of proximal tubules in the absence and presence of $2 \mathrm{mM}$ fructose. ${ }^{* * *} \mathrm{P}<0.001$ versus control $+\mathrm{S} 3226$ group.

Fig. 2. GLUT2, GLUT5 and KHK expression by LLCPK1 cells. Proteins were extracted from LLC-PK1 cells, subjected to SDS-PAGE and analyzed by immunoblotting. Representative immunoblot of GLUT2 (A), GLUT5 (B) and KHK (C) expression by LLC-PK1 cells. The molecular weights of the expected bands were 60$62 \mathrm{kDa}, \quad 49-60 \mathrm{kDa}$ and $33 \mathrm{kDa}$, respectively. $\mathrm{n}=3$ (independent experiments).

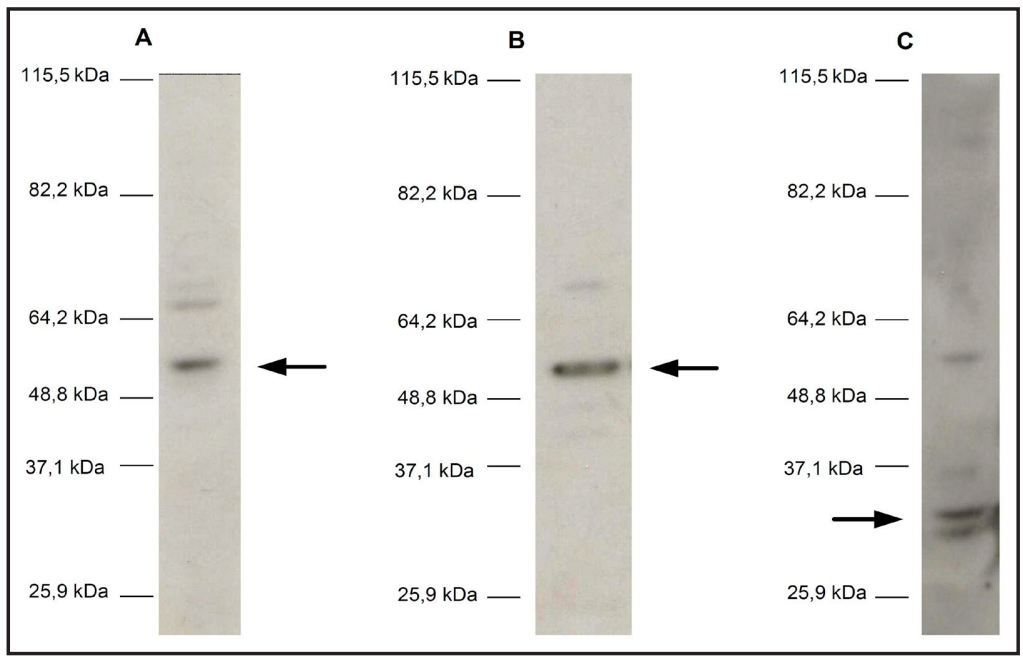

presence of S3226 in the luminal fluid $\left(0.8972 \pm 0.0750 \mathrm{nmol} / \mathrm{cm}^{2} \times \mathrm{s}\right.$ in control $+\mathrm{S} 3226$ group versus $1.058 \pm 0.082 \mathrm{nmol} / \mathrm{cm}^{2} \mathrm{x} \mathrm{s}$ in fructose $+\mathrm{S} 3226$ group). The effect of fructose on NHE3-mediated $\mathrm{HCO}_{3}^{-}$reabsorption is more evident when we analyze only the S3226sensitive component, which is calculated by the difference between the total $\mathrm{JHCO}_{3}{ }^{-}$and the $\mathrm{JHCO}_{3}{ }^{-}$in the presence of S3226 with or without fructose in the perfusion solution (1.185 \pm $0.075 \mathrm{nmol} / \mathrm{cm}^{2} \mathrm{x}$ s in control group versus $1.811 \pm 0.082 \mathrm{nmol} / \mathrm{cm}^{2} \mathrm{x} \mathrm{s}$ in fructose group, $\mathrm{P}$ $<0.0001$ ), as can be seen in Fig. 1C.

Expression of fructose transporters (GLUT2 and GLUT5) and Ketohexokinase (KHK) in LLC-PK1 cells

Expression of the main transporters that mediate fructose influx and of the enzyme that initiates its metabolism was examined by means of SDS-PAGE and immunoblotting, in order to verify if the LLC-PK1 cell line endogenously expresses these proteins. Figs. 2A and B show bands of approximately $60 \mathrm{kDa}$, confirming the expression of GLUT2 and GLUT5, respectively, in LLC-PK1 cells. The chance of cross-reaction between these two paralogs 


\section{Kidney \\ Blood Pressure \\ Research}

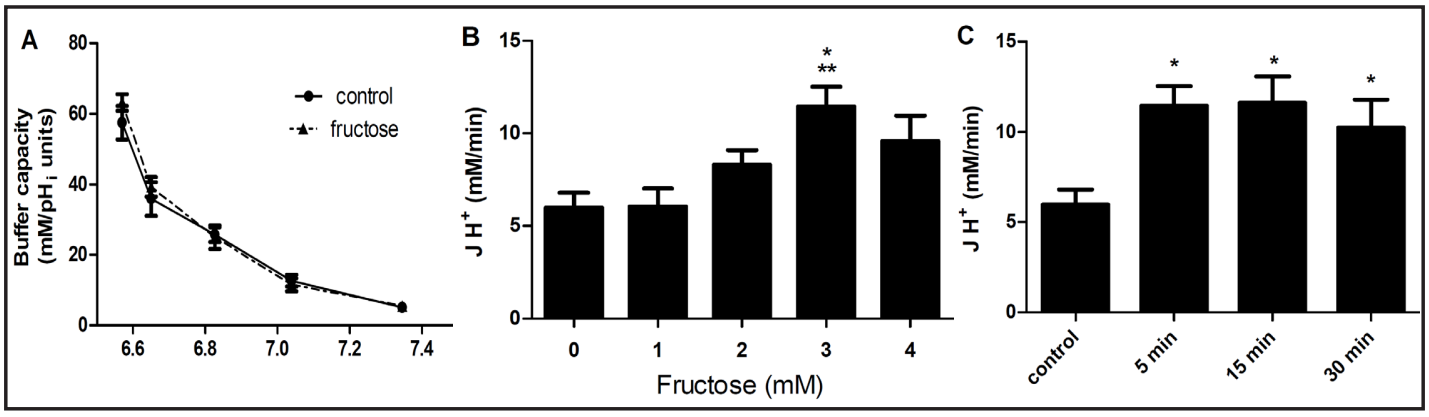

Fig. 3. Fructose stimulates the intracellular $\left(\mathrm{pH}_{\mathrm{i}}\right)$ recovery in LLC-PK1 cells. LLC-PK1 cells were grown to confluence on glass coverslips and loaded with $20 \mathrm{mM} \mathrm{NH}_{4} \mathrm{Cl}$ in a HEPES-buffered solution. After the acid pulse, the $\mathrm{pH}_{\mathrm{i}}$ recovery rate was analyzed. A: Estimated intrinsic buffering capacity plotted as a function of $\mathrm{pH}_{\mathrm{i}}$ in LLC-PK1 cells treated or not with $3 \mathrm{mM}$ fructose. B: Effect of different concentrations of fructose for $15 \mathrm{~min}$ on the $\mathrm{JH}^{+}$of LLC-PK1 cells. ${ }^{*} \mathrm{P}<0.05$ versus $1 \mathrm{mM}$ fructose group and ${ }^{* *} \mathrm{P}<0.01$ versus $0 \mathrm{mM}$ fructose (control group). $n=17(0 \mathrm{mM}), \mathrm{n}=9(1 \mathrm{mM}), \mathrm{n}=13(2 \mathrm{mM}), \mathrm{n}=6(3 \mathrm{mM})$ and $\mathrm{n}=8(4 \mathrm{mM})$. C: Time-response curve of $3 \mathrm{mM}$ fructose effect on $\mathrm{JH}^{+}$in LLC-PK1 cells. ${ }^{*} \mathrm{P}<0.05$ versus control group. $\mathrm{n}=17$ (control), $\mathrm{n}=6$ (5 $\mathrm{min}), \mathrm{n}=6$ (15 $\mathrm{min})$ and $\mathrm{n}=9$ (30 $\mathrm{min})$.

was very low, since alignment analysis of the aminoacid sequences using ClustalW software revealed that the sequences used to raise the antibodies showed low identity (approximately $17 \%$ in the region of GLUT2 epitope and 33\% in the region of GLUT5 epitope). This cell line also expresses the enzyme that initiates the fructose metabolism, KHK, as can be seen by the presence of a 33kDa band in SDS-PAGE and immunoblotting experiments (Fig. 2C).

Modulation of the $H^{+}$flux by fructose in LLC-PK1 cells

To evaluate whether fructose changes the intrinsic LLC-PK1 buffering capacity ( $\beta \mathrm{i}), \beta \mathrm{i}$ was calculated in the presence and absence of fructose. This carbohydrate does not exert any significant effect on $\beta_{i}$, as can be seen in Fig. $3 \mathrm{~A}$. We next examined the $\mathrm{Na}^{+}$dependent $\mathrm{pH}_{\mathrm{i}}$ recovery from an acid load in the presence and absence of fructose. LLC-PK1 cells were incubated with different fructose concentrations for a period of $15 \mathrm{~min}$ and we were able to observe that $3 \mathrm{mM}$ of this carbohydrate causes a significant increase in the $\mathrm{JH}^{+}$when compared to control cells $(11.44 \pm 1.092 \mathrm{mM} / \mathrm{min}$ in $3 \mathrm{mM}$ fructose group versus $5.985 \pm$ $0.823 \mathrm{mM} / \mathrm{min}$ in the control group, $\mathrm{P}<0.01$ ), as shown in Fig. 3B. A time course of fructose action on $\mathrm{JH}^{+}$was also analyzed and, as can be seen in Fig. 3C, 5 min of fructose treatment is sufficient to provoke a significant increase on $\mathrm{JH}^{+}$compared to control cells, and this increase was sustained for, at least, $30 \mathrm{~min}$.

\section{Fructose stimulates NHE3 activity in LLC-PK1 cells}

It is well known that LLC-PK1 cell line expresses NHE1 and NHE3 [34, 35]. In order to identify the main exchanger involved in the stimulatory effect of fructose on $\mathrm{JH}^{+}$in this cell line, experiments using specific inhibitors were performed. Previous data from our group have shown that both NHE isoforms are important for the maintenance of $\mathrm{pH}_{\mathrm{i}}$ in LLC-PK1 cells [36]. Here we confirm these results, since $10 \mu \mathrm{M}$ HOE694 (a NHE1 specific inhibitor) and $10 \mu \mathrm{M}$ S3226 (a NHE3 specific inhibitor) per se were able to significantly reduce the $\mathrm{JH}^{+}$ in LLC-PK1 cells. Our results also showed that there was a significant difference between the control (vehicle) and fructose groups in the presence of HOE694 $(2.996 \pm 0.702 \mathrm{mM} / \mathrm{min}$ in the vehicle + HOE694 group versus $7.319 \pm 1.280 \mathrm{mM} / \mathrm{min}$ in the fructose + HOE694 group, $\mathrm{P}<0.01$ ), which suggests that fructose was still able to stimulate $\mathrm{JH}^{+}$in the presence of the NHE1 inhibitor. However, there was no significant difference between the control (vehicle) and fructose groups in the presence of S3226 $(2.673 \pm 0.442 \mathrm{mM} / \mathrm{min}$ in the vehicle + S3226 group versus $2.024 \pm 0.397 \mathrm{mM} / \mathrm{min}$ in the fructose + S3226 group), suggesting that fructose was not able to stimulate $\mathrm{JH}^{+}$in the presence of the NHE3 inhibitor. Together, these findings 


\section{Kidney \\ Blood Pressure Research}

Kidney Blood Press Res 2012;36:320-334

\begin{tabular}{l|l}
\hline DOI: $10.1159 / 000343390$ & (c) 2012 S. Karger AG, Basel
\end{tabular}

Published online: December 12, 2012

www.karger.com/kbr

327

Queiroz-Leite/Crajoinas/Neri et al.: roximal Tubule NHE3 Stimulation by Fructose

Fig. 4. Fructose stimulates the NHE3 activity in LLCPK1 cells. LLC-PK1 cells were grown to confluence on glass coverslips and loaded with $20 \mathrm{mM} \mathrm{NH}_{4} \mathrm{Cl}$ in a HEPES-buffered solution. After the acid pulse, the $\mathrm{pH}_{\mathrm{i}}$ recovery rate was analyzed and expressed by $\mathrm{JH}^{+}$. Graph shows the effect of $3 \mathrm{mM}$ fructose on the $10 \mu \mathrm{M}$ HOE-694-dependent (NHE1) and the 10 $\mu \mathrm{M}$ S3226-dependent (NHE3) $\mathrm{pH}_{\mathrm{i}}$ recovery after an acid pulse, expressed by $\mathrm{JH}^{+} .{ }^{*} \mathrm{P}<0.05$ versus vehicle (1:5,000 DMSO), ${ }^{* *} \mathrm{P}<0.01$ versus vehicle, ${ }^{\&} \mathrm{P}<0.01$ versus vehicle + HOE694 and $\# \mathrm{P}<0.001$ versus fructose. $\mathrm{n}=6$ (vehicle), $\mathrm{n}=6$ (fructose), $\mathrm{n}=12$ (vehicle + HOE694), $\mathrm{n}=12$ (fructose + HOE694), $\mathrm{n}$ $=12($ vehicle + S3226) and $n=8$ (fructose + S3226).

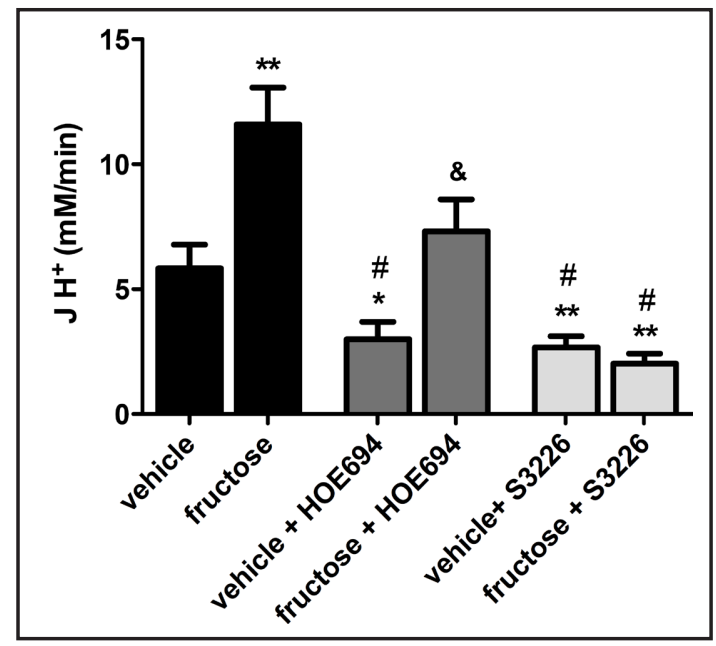

provide strong evidence that fructose increases $\mathrm{Na}^{+}$-dependent $\mathrm{JH}^{+}$after cell acidification by stimulating NHE3-mediated $\mathrm{Na}^{+} / \mathrm{H}^{+}$exchange activity. The results of this set of experiments are shown in Fig. 4.

Intracellular signaling pathways involved in the fructose-dependent stimulatory effect on NHE3 activity

Various stimuli can modulate NHE3 activity. Mitogen-activated protein kinase (MAPK) and cAMP-dependent protein kinase (PKA) pathways, among others, have been described to play a role in the regulation of NHE3 activity in intestinal and renal cells. These two signaling pathways were used as a starting point in the investigation of the intracellular mechanisms that were involved in the fructose stimulatory effect. To evaluate the participation of the MAPK pathway, proximal tubules were perfused with $50 \mu \mathrm{M}$ U0126, a MEK inhibitor. Our results have shown that this protein is involved in the basal regulation of NHE3 activity, since we found a significant decrease in $\mathrm{HCO}_{3}{ }^{-}$flux in the presence of the inhibitor when compared to the perfusion with control solution $\left(2.082 \pm 0.101 \mathrm{nmol} / \mathrm{cm}^{2} \mathrm{x} \mathrm{s}\right.$ in control group versus $1.314 \pm 0.096 \mathrm{nmol} / \mathrm{cm}^{2} \mathrm{x} \mathrm{s}$ in control + U0126 group, $\mathrm{P}<0.001$ ), as previously mentioned by Di Sole and Girardi [37]. MEK seems not to be involved in the stimulatory effect of fructose on $\mathrm{HCO}_{3}$ - flux, since this effect was still observed in the presence of U0126 $\left(1.314 \pm 0.096 \mathrm{nmol} / \mathrm{cm}^{2} \mathrm{x} \mathrm{s}\right.$ in control $+\mathrm{U} 0126$ group versus $2.336 \pm 0.156 \mathrm{nmol} / \mathrm{cm}^{2} \times \mathrm{s}$ in fructose + U0126 group, $\mathrm{P}<0.001$ ). These results can be observed in Fig. 5A. The same pattern of response was observed when we used $50 \mu \mathrm{M}$ SB203580, a p38 MAPK inhibitor. The perfusion with the inhibitor reduces significantly the $\mathrm{HCO}_{3}$ - flux compared to the perfusion with the control solution $\left(1.267 \pm 0.127 \mathrm{nmol} / \mathrm{cm}^{2} \mathrm{x}\right.$ s in control + SB203580 group versus $2.082 \pm 0.101 \mathrm{nmol} / \mathrm{cm}^{2} \times \mathrm{s}$ in control group, $\mathrm{P}<0.001$ ), which supports the hypothesis that this pathway participates in the basal regulation of NHE3 activity. Likewise, the use of the p38 MAPK inhibitor did not interfere with the NHE3 activation by fructose $(1.267 \pm 0.127$ $\mathrm{nmol} / \mathrm{cm}^{2} \mathrm{x}$ s in control + SB203580 group versus $2.028 \pm 0.134 \mathrm{nmol} / \mathrm{cm}^{2} \mathrm{x} \mathrm{s}$ in fructose + SB203580 group, $\mathrm{P}<0.01$ ), suggesting that this protein is not involved in the mechanisms that culminate at higher $\mathrm{HCO}_{3}{ }^{-}$reabsorption in the presence of fructose (Fig. 5B).

Since the PKA pathway is involved in downregulation of NHE3 activity, we evaluated the inhibition of this pathway in the stimulatory effect of fructose on NHE3 activity. We chose to use a drug that prevents the PKA holoenzyme from dissociation rather than the most commonly used drugs that block ATP binding sites, due to the demonstrated non-specific action of the latter on kinases other than PKA [38]. Our results shown that inhibition of PKA by $0.5 \mu \mathrm{M}$ of Rp-Adenosine 3', $5^{\prime}$-cyclic monophosphorothioate triethylammonium (Rp Adenosine) led to an increase in proximal NHE3 activity. As can be seen in Fig. 5C, the perfusion of $\mathrm{Rp}$ Adenosine alone significantly stimulated the $\mathrm{JHCO}_{3}^{-}$when compared to 


\section{Kidney \\ Blood Pressure \\ Research}

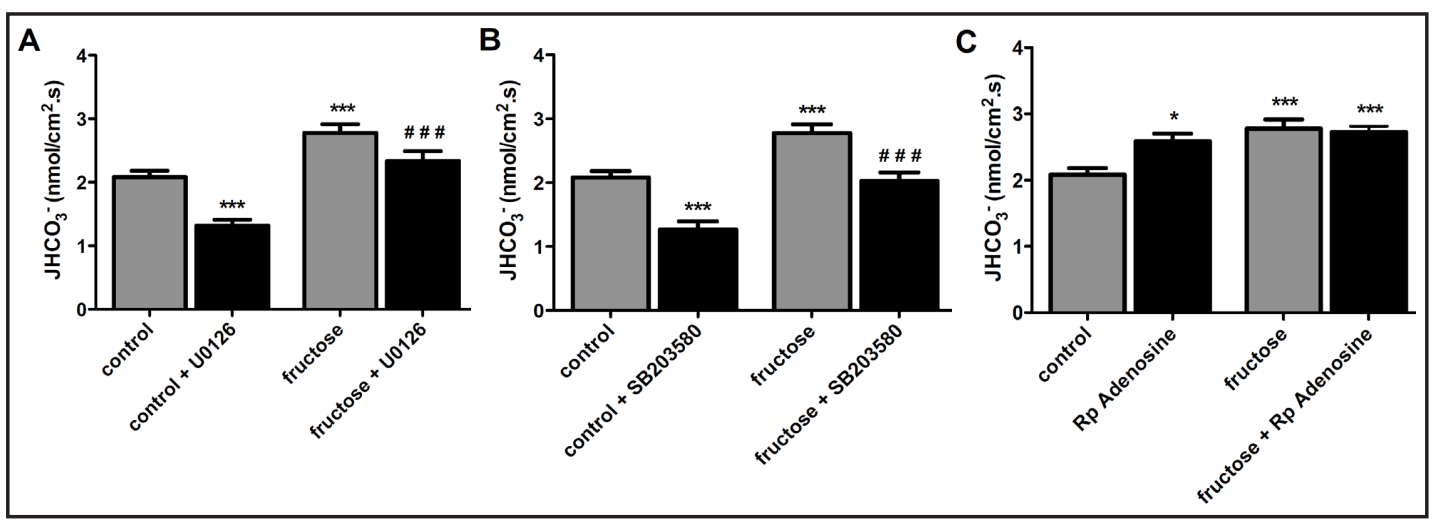

Fig. 5. PKA pathway, but not MAPK pathway was involved in the fructose-dependent stimulatory effect on NHE3 activity. A: The effect of $2 \mathrm{mM}$ fructose on $\mathrm{JHCO}_{3}{ }^{-}$was evaluated by stationary microperfusion and continuous measurement of luminal $\mathrm{pH}$ in the absence and presence of $50 \mu \mathrm{M}$ U0126, a MEK inhibitor. ${ }^{* * *} \mathrm{P}<$ 0.001 versus control group and ${ }^{\# \# \#} \mathrm{P}<0.001$ versus control $+\mathrm{U} 0126$ group. $\mathrm{n}=21$ (control), $\mathrm{n}=11$ (control + U0126), $n=17$ (fructose) and $n=12$ (fructose + U0126). B: The effect of $2 \mathrm{mM}$ fructose on $\mathrm{JHCO}_{3}^{-}$was evaluated by stationary microperfusion and continuous measurement of luminal $\mathrm{pH}$ in the absence and presence of $50 \mu \mathrm{M}$ SB203580, a MAPK inhibitor. ${ }^{* * *} \mathrm{P}<0.001$ versus control group and ${ }^{\# \# ~} \mathrm{P}<0.001$ versus control + SB203580 group. $n=21$ (control), $n=12$ (control + SB203580), $n=17$ (fructose) and $n=12$ (fructose + SB203580). C: The effect of $2 \mathrm{mM}$ fructose on $\mathrm{JHCO}_{3}{ }^{-}$was evaluated by stationary microperfusion and continuous measurement of luminal $\mathrm{pH}$ in the absence and presence of $10 \mu \mathrm{M}$ H89, a PKA catalytic subunit inhibitor. ${ }^{* *} \mathrm{P}<0.01$ and ${ }^{* * *} \mathrm{P}<0.001$ versus control group. $\mathrm{n}=21$ (control), $\mathrm{n}=17$ (control $+\mathrm{H} 89$ ), $\mathrm{n}=17$ (fructose) and $\mathrm{n}=13$ (fructose $+\mathrm{H89}$ ). $\mathrm{D}$ : The effect of $2 \mathrm{mM}$ fructose on $\mathrm{JHCO}_{3}{ }^{-}$was evaluated by stationary microperfusion and continuous measurement of luminal pH in the absence and presence of $1 \mu \mathrm{M}$ KT5720, a PKA catalytic subunit inhibitor. ${ }^{*} \mathrm{P}<0.05$ and ${ }^{* * *} \mathrm{P}<0.001$ versus control group. $\mathrm{n}=21$ (control), $\mathrm{n}=15$ (control $+\mathrm{KT} 5720), \mathrm{n}=17$ (fructose) $\mathrm{n}=15$ (fructose + KT5720). E: The effect of $2 \mathrm{mM}$ fructose on $\mathrm{JHCO}_{3}^{-}$was evaluated by stationary microperfusion and continuous measurement of luminal $\mathrm{pH}$ in the absence and presence of $0.5 \mu \mathrm{M}$ Rp-Adenosine 3',5'-cyclic monophosphorothioate triethylammonium (Rp Adenosine), a PKA regulatory subunit inhibitor. ${ }^{*} \mathrm{P}<0.05$ and ${ }^{* * *} \mathrm{P}<0.001$ versus control group. $\mathrm{n}=21$ (control), $\mathrm{n}=15$ (control + Rp Adenosine), $\mathrm{n}=17$ (fructose) $\mathrm{n}=15$ (fructose + Rp Adenosine).

control $\left(2.082 \pm 0.101 \mathrm{nmol} / \mathrm{cm}^{2} \mathrm{x} \mathrm{s}\right.$ in control group versus $2.585 \pm 0.117 \mathrm{nmol} / \mathrm{cm}^{2} \mathrm{x} \mathrm{s}$ in control + Rp Adenosine group, $\mathrm{P}<0.05$ ) and there was no significant difference between the fructose and the fructose + Rp Adenosine $\left(2.780 \pm 0.137 \mathrm{nmol} / \mathrm{cm}^{2} \times \mathrm{s}\right.$ in fructose versus $2.726 \pm 0.088 \mathrm{nmol} / \mathrm{cm}^{2} \mathrm{x}$ s in fructose $+\mathrm{Rp}$ Adenosine). The experiments using this specific PKA inhibitor showed that fructose at the luminal fluid mimicked the PKA inhibitor effect on the $\mathrm{JHCO}_{3}^{-}$and there was no additive stimulatory effect on $\mathrm{JHCO}_{3}^{-}$when fructose was added simultaneously with the PKA inhibitor. Taken together, these results suggest that the inhibition of the PKA signaling pathway mediates the fructose stimulatory effect on NHE3 activity.

Fructose-dependent stimulatory effect involves reduction of cAMP levels and NHE3 phosphorylation

As PKA activity is primarily related to intracellular cAMP levels, we measured the cAMP content of LLC-PK1 cells after 5, 15 and 30 min of fructose exposure in the presence of $10 \mu \mathrm{M}$ forskolin $+100 \mu \mathrm{M}$ IBMX. The results of these experiments showed that the cAMP content was significantly diminished at 5 and $15 \mathrm{~min}$ of fructose treatment $(44.8 \%, \mathrm{P}=0.0417$ and $31.5 \%, \mathrm{P}=0.009$ respectively, when compared to control groups of matched times) and despite of cAMP content was still decreased when the cells were incubated with fructose for $30 \mathrm{~min}$ (11.5\% compared to control cells), this difference was not statistically significant (Fig. 6A). 


\section{Kidney Blood Pressure Research}

Fig 6. Fructose reduces cAMP levels and NHE3 phosphorylation

on serine-552 without changing NHE3 total expression. A: Cells were grown to confluence and the cAMP levels were measured in the presence of $10 \mu \mathrm{M}$ forskolin (forsk), an adenylyl cyclase activator and $100 \mu \mathrm{M}$ 3-isobutyl-1methylxanthine (IBMX), a phosphodiesterase inhibitor, in the absence or presence for 5,15 and $30 \mathrm{~min}$ of $3 \mathrm{mM}$ fructose using a competitive assay. ${ }^{*} \mathrm{P}=0.0417$ versus control of 5 min and ${ }^{* *} \mathrm{P}=$ 0.0090 versus control of 15 $\min (\mathrm{n}=6)$. B: LLC-PK1 cells were grown to confluence on glass coverslips and treated with $10 \mu \mathrm{M}$ forskolin (Forsk) and $100 \mu \mathrm{M} \mathrm{IBMX}$, and treated or not with fructose for 15 min. Cells were loaded with $20 \mathrm{mM} \mathrm{NH} \mathrm{N}_{4} \mathrm{Cl}$ in a HEPESbuffered solution. After the acid pulse, the $\mathrm{pH}_{\mathrm{i}}$ recovery rate was analyzed and expressed by $\mathrm{JH}^{+} .{ }^{*} \mathrm{P}=0.029$

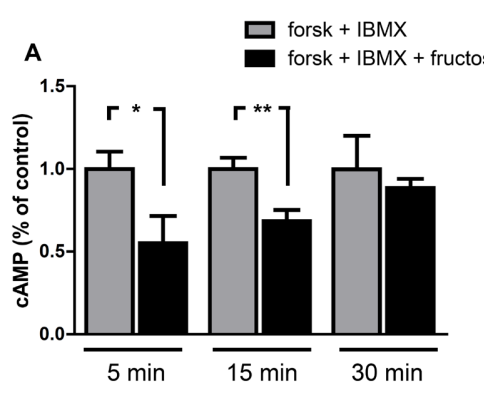

B

c
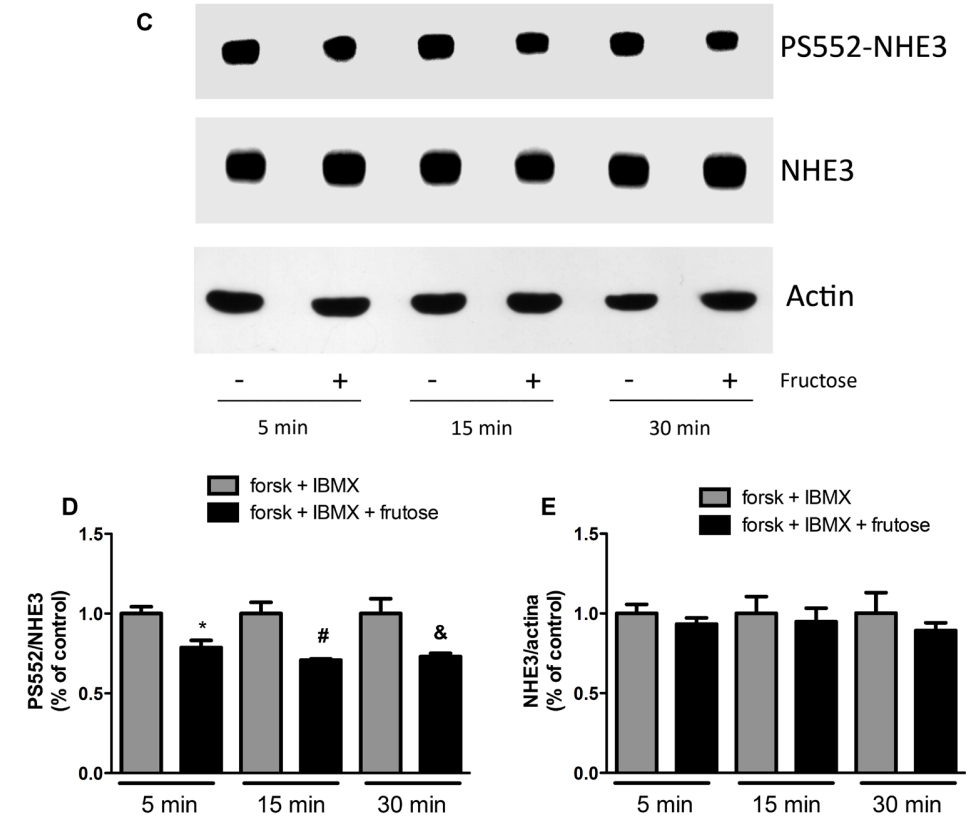

versus control group. $\mathrm{n}=8$ (control + Forsk + IBMX), $\mathrm{n}=6$ (fructose + Forsk + IBMX). C: Representative immunoblot of total, phosphorylated NHE3 at serine 552 and actin in $100 \mu \mathrm{g}$ of proteins extracted from

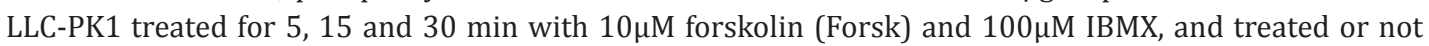
with $3 \mathrm{mM}$ fructose. Membranes were incubated with monoclonal antibodies against P-NHE3 at serine-552 $(1: 1,000)$, total NHE3 $(1: 500)$ and actin $(1: 50,000)$. D: Densitometric analysis of the ratio of P-NHE3 at serine 552 to total NHE3 (PS552/NHE3). ${ }^{*} \mathrm{P}=0.021$ versus Forsk + IBMX 5 min (control), ${ }^{*} \mathrm{P}=0.048$ versus Forsk + IBMX 15 min (control) and ${ }^{\&} \mathrm{P}=0.026$ versus Forsk + IBMX 30 min (control) as indicated by Student t-test. E: Densitometric analysis of the ratio of total NHE3 normalized to actin. Results are relative to three independent experiments performed in triplicate.

In order to verify whether the cAMP reduction was related to an increase in NHE3 activity in LLC-PK1 cells, $\mathrm{pH}$ recovery after acid pulse experiments were performed. There was a significant difference between the control and the fructose groups in the presence of $10 \mu \mathrm{M}$ forskolin $+100 \mu \mathrm{M}$ IBMX for $15 \mathrm{~min}$, as can be seen in Fig. 6B. The JH $\mathrm{H}^{+}$was stimulated from $5.177 \pm 0.386 \mathrm{mM} / \mathrm{min}$ in the forsk + IBMX group to $6.864 \pm 0.595 \mathrm{mM} / \mathrm{min}$ in the fructose + forsk + IBMX group, $\mathrm{P}=0.029$. These results suggest that the PKA signaling pathway was involved in the fructose-dependent NHE3 stimulation in the LLC-PK1 cells and that the molecular events unleashed by fructose in the rat proximal tubule have been preserved in this immortalized cell culture.

Examination of the phosphorylation status of NHE3 was performed by immunoblotting using a phosphospecific monoclonal antibody to NHE3 phosphorylated at serine-552 [30]. LLC-PK1 cells were treated for 5, 15 and 30 min with $10 \mu \mathrm{M}$ forskolin $+100 \mu \mathrm{M}$ IBMX and 


\section{Kidney \\ Blood Pressure Research}

Fig. 7. Fructose does not change NHE3 surface expression in LLC-PK1 cells. Confluent LLC-PK1 cells were treated or not with $3 \mathrm{mM}$ fructose for 5, 15 and $30 \mathrm{~min}$. Cell surface biotinylated proteins were subjected to SDS-PAGE and immunoblotting. Western blot analyses were performed with a monoclonal antibody against NHE3 (1:500). A: Representative immunoblot of surface NHE3 in $500 \mu \mathrm{g}$ of biotinylated proteins. B: graph shows the densitometric analysis of three independent experiments.

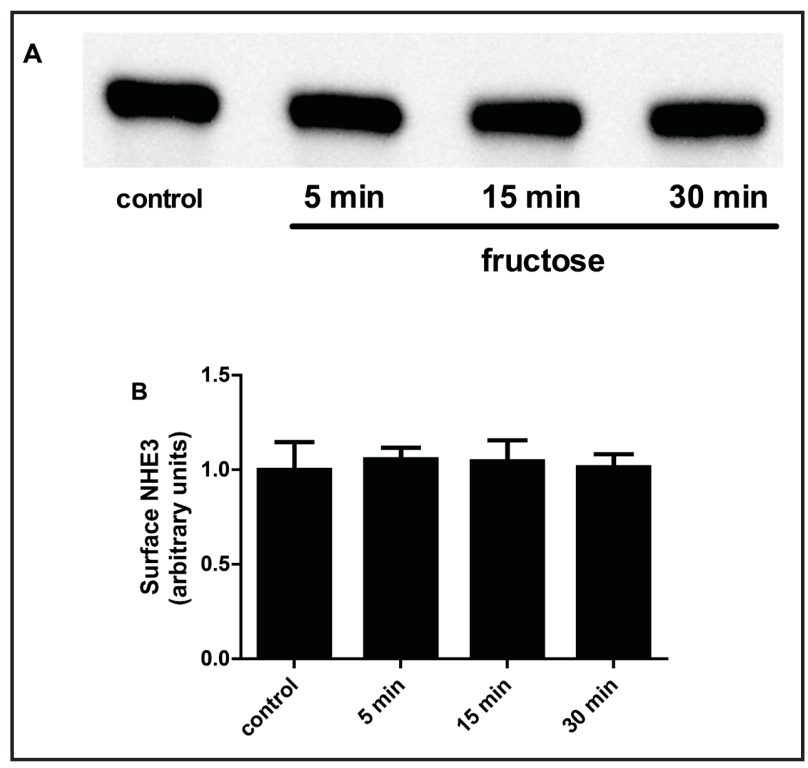

treated or not with $3 \mathrm{mM}$ of fructose. Fig. $6 \mathrm{C}$ shows a representative immunoblot of NHE3 phosphorylated at serine-552, total NHE3 and actin of cells treated or not with fructose for 5, 15 and $30 \mathrm{~min}$. The relative ratio of phosphorylated NHE3 to total NHE3 was lower in the fructose treated group in all periods of times studied. The presence of fructose reduced the NHE3 phosphorylation by $21.4 \%, 29.2 \%$ and $28.1 \%$ at 5, 15 and 30 minutes, respectively (Fig. 6D). Fig. 6E shows that the total amount of NHE3 normalized by the actin expression did not change with the fructose treatment at any given time.

\section{Surface NHE3 expression was not changed in the presence of fructose}

In order to investigate whether the reduction in the NHE3 phosphorylation was related to the increase of NHE3 presence in the plasma membrane, biotinylation experiments were performed. LLC-PK1 cells were treated or not with fructose for 5, 15 and $30 \mathrm{~min}$. We were not able to see any difference in the amount of NHE3 in the plasma membrane in cells treated or not with fructose for 5, 15 and 30 min (Fig. 7A). The densitometric analysis of three independent experiments is shown in Fig. 7B.

\section{Discussion}

It has been demonstrated that fructose causes a sodium-sensitive increase in blood pressure [22] and acutely reduces the urinary $\mathrm{Na}^{+}$excretion [20], suggesting that this hexose may regulate the activity of renal tubular sodium transporters. The present work aimed to evaluate the role of fructose in modulating renal proximal NHE3 activity and elucidate the molecular mechanisms underlying this modulation. Here we report that fructose stimulates NHE3 activity, which increases proximal tubule $\mathrm{Na}^{+}$reabsorption. We also show that the molecular mechanisms involved in this process are mediated, at least in part, by downregulation of the PKA signaling pathway.

Previous microperfusion experiments performed in proximal tubules in situ demonstrated that NHE3 is the principal apical membrane pathway for $\mathrm{HCO}_{3}{ }^{-}$reabsorption [33], whereas the V-type $\mathrm{H}^{+}$ATPase accounts for 20 to $30 \%$ of the total $\mathrm{HCO}_{3}^{-}$reabsorption in this nephron segment [39]. Our results demonstrated that net $\mathrm{HCO}_{3}^{-}$flux is significantly increased in the presence of 2 and $3 \mathrm{mM}$ fructose in the luminal proximal tubular fluid, whereas $1 \mathrm{mM}$ of this carbohydrate did not exert such an effect. The use of S3226, a specific NHE3 inhibitor, confirms that increased NHE3 activity is the responsible for the higher $\mathrm{HCO}_{3}{ }^{-}$ reabsorption observed in presence of fructose. 


\section{Kidney Blood Pressure Research}

Microperfusion experiments associated with a pharmacological approach were used to identify the intracellular signaling pathways involved in the fructose-dependent stimulatory effect on NHE3 activity. The present set of experiments showed that both MEK and MAPK were involved in maintenance of the basal NHE3 activity, but they did not interfere with the fructose effect. On the other hand, the PKA signaling pathway showed to be involved in the fructose-dependent stimulatory effect on NHE3 activity. Proximal tubules were perfused with a specific PKA regulatory subunit inhibitor and we observed that fructose or PKA inhibitor induce the same effect on $\mathrm{HCO}_{3}{ }^{-}$flux, with no additive effect, suggesting that the PKA pathway downregulation is, at least in part, responsible for the observed fructose stimulation of NHE3 activity.

Our experiments attested that our cell model preserved the fructose/PKA-dependent NHE3 stimulatory mechanism, which was very helpful to investigate the molecular events underlying this response. We have observed a significant decrease in endogenous cAMP levels in the presence of fructose in this cell line, which is consistent with reduced PKA activity. NHE3 activity measured by $\mathrm{JH}^{+}$in LLC-PK1 cells was increased in the presence of fructose for $15 \mathrm{~min}$, the same period of time in which we found a significant reduction in cAMP levels. Together, these results suggest that downregulation of PKA is involved in the fructose stimulatory effect on NHE3 activity.

It is well known that acute NHE3 regulation involves the interplay of multiple intracellular signaling cascades, including the modulation of adenylyl cyclase [40]. Several studies have highlighted the importance of PKA phosphorylation on NHE3 activity modulation [41-43]; however, how exactly NHE3 phosphorylation contributes to its regulation is not well known. Studies performed in spontaneously hypertensive rats (SHR) showed an inverse correlation between the levels of NHE3 phosphorylation at serine-552 and NHE3 activity [44]. In this work it was observed that young SHR presented lower levels of NHE3 phosphorylation at serine-552 and higher NHE3 activity compared to age matched Wistar Kyoto rats, whereas adult SHR presented higher NHE3 phosphorylation at serine-552 and lower NHE3 activity compared to age matched Wistar Kyoto rats [44]. The results of the present study also showed an inverse correlation between NHE3 phosphorylation at serine-552 and NHE3 activity in LLC-PK1 cells. We found that NHE3 activity was enhanced in the presence of fructose, whereas we observed a significant reduction in NHE3 phosphorylation at serine- 552 .

Phosphorylation of the 552 residue has been implicated in NHE3 subcellular trafficking $[30,45]$. We were not able to find any change in the NHE3 amount at the membrane surface in the presence of fructose, which suggests that the reduction in Ser-552 phosphorylation is not associated to higher NHE3 translocation to the cell surface. Considering that NHE3 phosphorylation itself may not be sufficient to induce changes in NHE3 activity [45], fructose might induce a shift in the NHE3 binding pattern with accessory proteins or alter the transport rate by other unknown mechanisms.

Several groups have extensively demonstrated the link between high fructose intake and the development of clinical symptoms and biochemical changes found in metabolic syndrome, both in studies using human subjects and animal models [46-49]. Furthermore, the potential role of fructose in causing hypertension and diabetes raises the possibility that this carbohydrate may also have a role in chronic kidney disease [1]. NHE3 is responsible for the reabsorption of approximately $70 \%$ of the filtered $\mathrm{Na}^{+}$in proximal tubules and, although important regulatory mechanisms exist in distal nephron, the stimulation of $\mathrm{Na}^{+}$reabsorption from proximal tubules also contributes to the increase in extracellular volume, and might have a role in the development of hypertension [50,51]. The key role of the proximal tubule in the blood pressure homeostasis was clearly demonstrated by the significant reduction in systolic blood pressure when angiotensin type 1 receptors (AT1aR) were knocked out only in this nephron segment [52]. This location is critical for integrating signals to set the level of intra-arterial pressure, through modulation of tubular fluid reabsorption and regulation of the $\mathrm{Na}^{+}$transporter expression [52]. Future studies are needed to address whether fructosestimulated proximal NHE3 activity may contribute to renal injury and hypertension. 


\section{Kidney \\ Blood Pressure Research}

Queiroz-Leite/Crajoinas/Neri et al.: roximal Tubule NHE3 Stimulation by Fructose

\section{Conclusion}

Taken together, our results point toward a stimulatory effect of fructose on proximal NHE3 activity through mechanisms related to reduced cAMP levels and reduced NHE3 phosphorylation at serine-552 by PKA. Fructose-dependent NHE3 stimulation may be, at least in part, responsible for the increase in $\mathrm{Na}^{+}$and fluid reabsorption, which may contribute to the onset of hypertension in fructose-fed models of metabolic syndrome. Chronic studies are underway to test this hypothesis.

\section{Conflict of Interests}

The authors declare no conflicts of interest, financial or otherwise.

\section{Acknowledgments}

The authors gratefully acknowledge the suggestions and advice of Thaissa Dantas Pessoa. This study was supported by FAPESP (Fundação de Amparo à Pesquisa do Estado de São Paulo), grants 2012/04150-4 to G.D.Q.L; 07/52945-8 to A.C.C.G. and 08/58287-5 to G.M. and CNPq (Conselho Nacional de Desenvolvimento Científico e Tecnológico).

\section{References}

-1 Johnson RJ, Sanchez-Lozada LG, Nakagawa T: The effect of fructose on renal biology and disease. J Am Soc Nephrol 2010;21:2036-2039.

-2 Elliott SS, Keim NL, Stern JS, Teff K, Havel PJ: Fructose, weight gain, and the insulin resistance syndrome. Am J ClinNutr 2002;76:911-922.

- Mayes PA: Intermediary metabolism of fructose. Am J Clin Nutr 1993;58:754S-765S.

4 Diggle CP, Shires M, Leitch D, Brooke D, Carr IM, Markham AF, Hayward BE, Asipu A, Bonthron DT: Ketohexokinase: Expression and localization of the principal fructose-metabolizing enzyme. J Histochem Cytochem 2009;57:763-774.

$>5$ Douard V, Ferraris RP: Regulation of the fructose transporter glut5 in health and disease. Am J Physiol Endocrinol Metab 2008;295:E227-E237.

6 Manolescu AR, Witkowska K, Kinnaird A, Cessford T, Cheeseman C: Facilitated hexose transporters: New perspectives on form and function. Physiology (Bethesda) 2007;22:234-240.

7 Johnson RJ, Segal MS, Sautin Y, Nakagawa T, Feig DI, Kang DH, Gersch MS, Benner S, Sanchez-Lozada LG: Potential role of sugar (fructose) in the epidemic of hypertension, obesity and the metabolic syndrome, diabetes, kidney disease, and cardiovascular disease. Am J Clin Nutr 2007;86:899-906.

-8 Ferder L, Ferder MD, Inserra F: The role of high-fructose corn syrup in metabolic syndrome and hypertension. Curr Hypertens Rep 2010;12:105-112.

-9 Tappy L, Le KA: Metabolic effects of fructose and the worldwide increase in obesity. Physiol Rev 2010;90:23-46.

10 Tran LT, Yuen VG, McNeill JH: The fructose-fed rat: A review on the mechanisms of fructose-induced insulin resistance and hypertension. Mol Cell Biochem 2009;332:145-159.

11 Basciano H, Federico L, Adeli K: Fructose, insulin resistance, and metabolic dyslipidemia. Nutr Metab (Lond) 2005;2:5.

12 Chen J, Muntner P, Hamm LL, Jones DW, Batuman V, Fonseca V, Whelton PK, He J: The metabolic syndrome and chronic kidney disease in u.S. Adults. Ann Intern Med 2004;140:167-174.

13 Shoham DA, Durazo-Arvizu R, Kramer H, Luke A, Vupputuri S, Kshirsagar A, Cooper RS: Sugary soda consumption and albuminuria: Results from the national health and nutrition examination survey, 19992004. PLoSOne 2008;3:e3431. 


\section{Kidney \\ Blood Pressure Research}

14 Gersch MS, Mu W, Cirillo P, Reungjui S, Zhang L, Roncal C, Sautin YY, Johnson RJ, Nakagawa T: Fructose, but not dextrose, accelerates the progression of chronic kidney disease. Am J Physiol Renal Physiol 2007;293:F1256-F1261.

15 Sanchez-Lozada LG, Tapia E, Jimenez A, Bautista P, Cristobal M, Nepomuceno T, Soto V, Avila-Casado C, Nakagawa T, Johnson RJ, Herrera-Acosta J, Franco M: Fructose-induced metabolic syndrome is associated with glomerular hypertension and renal microvascular damage in rats. Am J Physiol Renal Physiol 2007;292:F423-F429.

-16 Cirillo P, Gersch MS, Mu W, Scherer PM, Kim KM, Gesualdo L, Henderson GN, Johnson RJ, Sautin YY: Ketohexokinase-dependent metabolism of fructose induces proinflammatory mediators in proximal tubular cells. J Am Soc Nephrol 2009;20:545-553.

-17 Nakayama T, Kosugi T, Gersch M, Connor T, Sanchez-Lozada LG, Lanaspa MA, Roncal C, Perez-Pozo SE, Johnson RJ, Nakagawa T: Dietary fructose causes tubulointerstitial injury in the normal rat kidney. Am J Physiol Renal Physiol 2010;298:F712-F720.

18 Meneton P, Jeunemaitre X, de Wardener HE, MacGregor GA: Links between dietary salt intake, renal salt handling, blood pressure, and cardiovascular diseases. Physiol Rev 2005;85:679-715.

19 Soleimani M: Dietary fructose, salt absorption and hypertension in metabolic syndrome: Toward a new paradigm. Acta Physiol (Oxf) 2011;201:55-62.

-20 Singh AK, Amlal H, Haas PJ, Dringenberg U, Fussell S, Barone SL, Engelhardt R, Zuo J, Seidler U, Soleimani M: Fructose-induced hypertension: Essential role of chloride and fructose absorbing transporters pat1 and glut5. Kidney Int 2008;74:438-447.

21 Soleimani M, Alborzi P: The role of salt in the pathogenesis of fructose-induced hypertension. Int J Nephrol 2011;2011:392708.

-22 Catena C, Cavarape A, Novello M, Giacchetti G, Sechi LA: Insulin receptors and renal sodium handling in hypertensive fructose-fed rats. Kidney Int 2003;64:2163-2171.

-23 Lessa LM, Amorim JB, Fonteles MC, Malnic G: Effect of renoguanylin on hydrogen/bicarbonate ion transport in rat renal tubules. Regul Pept 2009;157:37-43.

24 De Mello AM, Lopes MJ, Malnic G: Pco2 in renal cortex. Am J Physiol 1990;259:F357-F365.

25 Carraro-Lacroix LR, Ramirez MA, Zorn TM, Reboucas NA, Malnic G: Increased nhe1 expression is associated with serum deprivation-induced differentiation in immortalized rat proximal tubule cells. Am J Physiol Renal Physiol 2006;291:F129-F139.

26 Boyarsky G, Ganz MB, Sterzel RB, Boron WF: Ph regulation in single glomerular mesangial cells. I. Acid extrusion in absence and presence of hco3. Am J Physiol 1988;255:C844-C856.

27 Weintraub WH, Machen TE: Ph regulation in hepatoma cells: Roles for na-h exchange, cl-hco3 exchange, and na-hco3 cotransport. Am J Physiol 1989;257:G317-G327.

28 Girardi AC, Knauf F, Demuth HU, Aronson PS: Role of dipeptidyl peptidase iv in regulating activity of na+/ $\mathrm{h}+$ exchanger isoform nhe3 in proximal tubule cells. Am J Physiol Cell Physiol 2004;287:C1238-C1245.

29 Lowry OH, Rosebrough NJ, Farr AL, Randall RJ: Protein measurement with the folin phenol reagent. J Biol Chem 1951;193:265-275.

-30 Kocinsky HS, Girardi AC, Biemesderfer D, Nguyen T, Mentone S, Orlowski J, Aronson PS: Use of phosphospecific antibodies to determine the phosphorylation of endogenous na $+\mathrm{h}+$ exchanger nhe3 at pka consensus sites. Am J Physiol Renal Physiol 2005;289:F249-F258.

-31 Biemesderfer D, Rutherford PA, Nagy T, Pizzonia JH, Abu-Alfa AK, Aronson PS: Monoclonal antibodies for high-resolution localization of nhe3 in adult and neonatal rat kidney. Am J Physiol 1997;273:F289-F299.

32 Schwark JR, Jansen HW, Lang HJ, Krick W, Burckhardt G, Hropot M: S3226, a novel inhibitor of na+/h+ exchanger subtype 3 in various cell types. Pflugers Arch 1998;436:797-800.

-33 Wang T, Hropot M, Aronson PS, Giebisch G: Role of nhe isoforms in mediating bicarbonate reabsorption along the nephron. Am J Physiol Renal Physiol 2001;281:F1117-F1122.

34 Reilly RF, Hildebrandt F, Biemesderfer D, Sardet C, Pouyssegur J, Aronson PS, Slayman CW, Igarashi P: Cdna cloning and immunolocalization of a na(+)-h+ exchanger in llc-pk1 renal epithelial cells. Am J Physiol 1991;261:F1088-F1094.

35 Shugrue CA, Obermuller N, Bachmann S, Slayman CW, Reilly RF: Molecular cloning of nhe3 from llc-pk1 cells and localization in pig kidney. J Am Soc Nephrol 1999;10:1649-1657. 


\section{Kidney \\ Blood Pressure Research}

Kidney Blood Press Res 2012;36:320-334

\begin{tabular}{l|l}
\hline DOI: $10.1159 / 000343390$ & (c) 2012 S. Karger AG, Basel \\
\hline
\end{tabular}

Published online: December 12, 2012

www.karger.com/kbr

Queiroz-Leite/Crajoinas/Neri et al.: roximal Tubule NHE3 Stimulation by Fructose

-36 Carraro-Lacroix LR, Malnic G, Girardi AC: Regulation of na+/h+ exchanger nhe3 by glucagon-like peptide 1 receptor agonist exendin-4 in renal proximal tubule cells. Am J Physiol Renal Physiol 2009;297:F16471655.

-37 Di SF, Girardi AC: Uncovering the pathway of sepsis-induced renal tubular dysfunction. Focus on "basolateral lps inhibits nhe3 and hcoformula absorption through tlr4/myd88-dependent erk activation in medullary thick ascending limb". Am J Physiol Cell Physiol 2011;301:C1290-C1292.

-38 Davies SP, Reddy H, Caivano M, Cohen P: Specificity and mechanism of action of some commonly used protein kinase inhibitors. Biochem J 2000;351:95-105.

39 Ulate G, Fernandez R, Malnic G: Effect of bafilomycin on proximal bicarbonate absorption in the rat. Braz J Med Biol Res 1993;26:773-777.

40 Wakabayashi S, Shigekawa M, Pouyssegur J: Molecular physiology of vertebrate na+/h+ exchangers. Physiol Rev 1997;77:51-74.

-41 Kurashima K, Yu FH, Cabado AG, Szabo EZ, Grinstein S, Orlowski J: Identification of sites required for down-regulation of na+/h+ exchanger nhe3 activity by camp-dependent protein kinase. Phosphorylationdependent and -independent mechanisms. J Biol Chem 1997;272:28672-28679.

$\checkmark 42$ Moe OW, Amemiya M, Yamaji Y: Activation of protein kinase a acutely inhibits and phosphorylates na/h exchanger nhe-3. J Clin Invest 1995;96:2187-2194.

43 Zhao H, Wiederkehr MR, Fan L, Collazo RL, Crowder LA, Moe OW: Acute inhibition of na/h exchanger nhe-3 by camp. Role of protein kinase a and nhe-3 phosphoserines 552 and 605. J Biol Chem 1999;274:39783987.

44 Crajoinas RO, Lessa LM, Carraro-Lacroix LR, Davel AP, Pacheco BP, Rossoni LV, Malnic G, Girardi AC: Posttranslational mechanisms associated with reduced nhe3 activity in adult vs. Young prehypertensive shr. Am J Physiol Renal Physiol 2010;299:F872-F881.

-45 Kocinsky HS, Dynia DW, Wang T, Aronson PS: Nhe3 phosphorylation at serines 552 and 605 does not directly affect nhe3 activity. Am J Physiol Renal Physiol 2007;293:F212-F218.

46 Le KA, Ith M, Kreis R, Faeh D, Bortolotti M, Tran C, Boesch C, Tappy L: Fructose overconsumption causes dyslipidemia and ectopic lipid deposition in healthy subjects with and without a family history of type 2 diabetes. Am J Clin Nutr 2009;89:1760-1765.

-47 Stanhope KL, Schwarz JM, Keim NL, Griffen SC, Bremer AA, Graham JL, Hatcher B, Cox CL, Dyachenko A, Zhang W, McGahan JP, Seibert A, Krauss RM, Chiu S, Schaefer EJ, Ai M, Otokozawa S, Nakajima K, Nakano T, Beysen C, Hellerstein MK, Berglund L, Havel PJ: Consuming fructose-sweetened, not glucose-sweetened, beverages increases visceral adiposity and lipids and decreases insulin sensitivity in overweight/obese humans. J Clin Invest 2009;119:1322-1334.

48 Brown CM, Dulloo AG, Yepuri G, Montani JP: Fructose ingestion acutely elevates blood pressure in healthy young humans. Am J Physiol Regul Integr Comp Physiol 2008;294:R730-R737.

-49 Hwang IS, Ho H, Hoffman BB, Reaven GM: Fructose-induced insulin resistance and hypertension in rats. Hypertension 1987;10:512-516.

-50 Horita S, Seki G, Yamada H, Suzuki M, Koike K, Fujita T: Insulin resistance, obesity, hypertension, and renal sodium transport. Int J Hypertens 2011;2011:391762.

-51 Girardi AC, Di Sole F: Deciphering the mechanisms of the na+ $\mathrm{h}+$ exchanger-3 regulation in organ dysfunction. Am J Physiol Cell Physiol 2012;302:C1569-1587.

52 Gurley SB, Riquier-Brison AD, Schnermann J, Sparks MA, Allen AM, Haase VH, Snouwaert JN, Le TH, McDonough AA, Koller BH, Coffman TM: At1a angiotensin receptors in the renal proximal tubule regulate blood pressure. Cell Metab 2011;13:469-475. 